\title{
Development, Dependency and HIV Risk in Kiribati
}

\author{
Karen McMillan, Heather Worth* \\ School of Public Health and Community Medicine, University of New South Wales, Sydney, Australia \\ Email: k.mcmillan@unsw.edu.au, ${ }^{*}$ h.worth@unsw.edu.au
}

Received 17 April 2014; revised 15 May 2014; accepted 5 June 2014

Copyright (C) 2014 by authors and Scientific Research Publishing Inc.

This work is licensed under the Creative Commons Attribution International License (CC BY). http://creativecommons.org/licenses/by/4.0/

c) (i) Open Access

\section{Abstract}

A study was undertaken in Kiribati, a small Pacific island nation, that has a low-level HIV epidemic but a high incidence of STIs among seafarers, their spouses (and children), and those involved in sex work. There are connections between development and dependency and HIV risk in Kiribati. Kiribati is a peripheral and dependent small island state underwritten by conditional aid and financial assistance and advice from donor countries, entwined in, and subject to, external globalising processes. We found two major factors related to Kiribati's dependency engendered HIV risk. The first is Kiribati's reliance on transnational seafaring. Long periods away from home, shipboard and port mateship cultures, and infrequent condom use in casual and paid sexual relations while in overseas ports, exacerbated by heavy alcohol use, have rendered i-Kiribati seafarers vulnerable to HIV. The second factor is related to the labour force participation of young women, which is extremely limited. In this context, some young i-Kiribati women choose to work on board, foreign fishing vessels selling sex. They stay with one client while on board a boat-for up to three months-and sex work is not only an economic transaction, but also emotional and affective labour. It is a pattern that makes consistent condom use problematic. Having multiple sequential seafarer partners may in fact generate considerable HIV vulnerability.

\section{Keywords}

HIV, Globalisation, Seafarers, Sex Work, Kiribati

\section{Introduction}

But what AIDS also makes jarringly visible is that these conundrums of inclusion and exclusion, human emancipation and inhuman neglect are caught up in an ongoing dialectic, both positive and negative, of history and

*Corresponding author. 
power, capital and geopolitics. Thus the disease, like Hurricane Katrina or the burning banlieus of Paris, also lays bare the colonial frontiers etched across the ostensibly integrated landscape of our brave neo world [1].

A range of social and economic factors underpin the direction, extent and character of the HIV epidemic in developing countries [2]-[5]. As Singer points out [6], "the structure of social relations that grow out of the system of economic production may have particular importance" in understanding the specifics of HIV in time and space. Recently, there has been a renewed emphasis on the structural drivers of the epidemic [7] [8]. Foller and Thorn argue that HIV must be understood within the matrix configured by contemporary globalisation, and that it is "embedded in the power structures of modern society" [9]. Within this global framework, rather than HIV risk being the domain of the individual who lacks the tools to practise safe sex, vulnerability to infection must be viewed in relation to unequal trade, international divisions of labour, and exercises of global power that promote unequal relationships between developed and emerging nations [10]-[12]. HIV both shapes and is shaped by the West's development project. For there is no doubt that HIV has hit hardest in those parts of the world where "development", policies of structural adjustment, and free trade abound. Lack of control over the production of resources [13] and enforced disempowerment of the periphery are not only a "cause" of HIV; they also inhibit effective national responses to the virus.

Kiribati is a small island republic located in the central Pacific, consisting of 32 mostly low-lying islands widely scattered across 3000 kilometres of ocean, with a population of just over 100,000. The population profile is young, with 38\% being under the age of 15 years [14]. The incidence of STIs is high in Kiribati. A 2008 surveillance survey of antenatal women aged 15 - 46 years found an average prevalence of chlamydia at $11 \%$ and syphilis at 5\% [15]. Kiribati is experiencing a low-level general HIV epidemic: it had 55 cumulative confirmed HIV cases on December 2011, representing an HIV prevalence of 0.053 per 100,000 [15]. Two-thirds of those diagnosed with HIV are men [16], although a more even gender balance emerges among new cases over the last decade. The main mode of transmission is understood to have been heterosexual sex, followed by perinatal transmission.

Groups were identified to be most at risk including seafarers, their spouses (and children) and those involved in commercial or transactional sex [15]. This leads us to consider the connections between development and dependency and HIV risk in Kiribati. In doing so, we bring together two somewhat disparate streams of research: one on the political economy of development, and the other on empirical research on HIV risk in Kiribati. We attempt to take up what Jean and John Comaroff call "the challenge involved in grasping, ethnographically; the processes by which those world-historical forces were being made meaningful and tractable by the human beings in question" [17]. This approach has a macro-analytic and materialist focus [18] where we will not only challenge that conceptualisation of HIV risk in resource-poor settings inherent in risk group positioning emphasises individual actions, but argue for a political economy of the virus.

Our article is underpinned by empirical data: data on Kiribati's economy and social structure; sex workers' accounts of the negotiation of HIV risk in Kiribati's mainport town; and second-generation HIV surveillance data of i-Kiribati seafarers. It attempts to show how people's HIV risk inheres in global political-economic forces-forces that operate independently of the people whose experiences and HIV status are the grounds for those data [19] [20]. Paul Farmer contends that "history and its calculus of economic and symbolic power impinge on the local and the personal" [21]. Enquiries into drivers and determinants of local HIV risk begin with the analysis of data gathered from and on individuals, yet the global and historical forces that shape individual experiences are beyond individual control. In acknowledgement of this, we want not only to describe local experiences of social phenomenon, but also to conceptualise the global processes of development and dependency that lie behind these phenomena.

\section{The Political Economy of Kiribati}

In a MIRAB ${ }^{1}$ economy the indigenous population maximize their material well-being by management of the globalization process [22].

Kiribati is a tiny atoll nation with very limited land and little freshwater. The urban areas are overcrowded and poorly serviced. Kiribati is extremely poor. It has had negative gross domestic product (GDP) growth (even prior to the global financial crisis); only $14 \%$ of adults are in paid employment; $21.7 \%$ of the population is below the poverty line; the under-five mortality rate is 46.0 per 1000 live births; and only 64\% of i-Kiribati have

\footnotetext{
${ }^{1}$ An acronym for economies reliant on migration, remittances, aid and bureaucracy.
} 
safe drinking water [23].

Kiribati is unlikely to meet any of its Millennium Development Goals by 2015 [24]. Its political economy, like that of many other small island states, evidences broader global power relations. Kiribati is an economically fragile state with considerable structural constraints to independence because of its geographical isolation and concomitant extreme vulnerabilities [25]. While Kiribati has vast ocean territories full of tuna-and has also had the benefit of interest from the reserve equalisation fund [26] created from previous phosphate mining - it is essentially a MIRAB economy [27]. This means that because of its restricted size, resource base and low GDP, Kiribati-like many other small island states in the Pacific — has had to rely on migration (of labour), remittances and aid to survive. The International Labour Organization argues that the MIRAB process "has turned Kiribati into a rent-based economy where income is generated from remittances and aid flows rather than productive activities. This has skewed the occupational structure towards the bureaucracy, non-agricultural activities and overseas employment [28]. External revenue sources are the economy's bedrock, with gross national income largely derived from fishing fees, profits from the stabilisation Revenue Equalisation Reserve Fund, and remittances from seamen and others. For example, the public sector remains the main deliverer of social services and utilities; at nearly $40 \%$ of GDP, the public wage bill in Kiribati is higher than in any other Pacific country. In 2011 and 2012, i-Kiribati men working on foreign vessels sent remittances of US\$10 million and US\$12 million annually, accounting for around 20\% of Kiribati's GDP [29].

While MIRAB has advantages for small island states such as Kiribati [22], it also ensures international dependency and appears not to have a significant effect in reducing domestic poverty or alleviating structural constraints on individual and societal agency with regard to income or employment options [30]. Kiribati has been unable in recent years to generate economic growth and, according to the 2008 Pacific Economic Survey, "rapid growth may never be achieved, so... [Kiribati] should focus on prudent application of aid and fishing rents, and maximising remittances" [24]. Increasingly enmeshed in international abundant networks, Kiribati's designation as a peripheral and dependent small island state in a world system may be irrevocable [31]. Conditional aid and financial assistance and advice from donor countries underwrite this dependence and constraint, ensuring that Kiribati remains entwined in, and subject to, external globalising processes. These processes, combined with reduced foreign aid and internal socioeconomic dynamics, have resulted in major stressors for the economy and governance of Kiribati-and for the people who live there.

The territory of Kiribati includes little habitable and almost no productive land, but vast areas of ocean. The Pacific Ocean, with its abundant marine resources, has been central to the shaping of the culture and economy of Kiribati. The Western and Central Pacific are home to the world's largest and most valuable tuna fishery. Industrial fisheries are tuna-related-almost 10 times greater than the other fisheries combined. Holding $29 \%$ of the Pacific's skipjack tuna, Kiribati's marine territory is its greatest resource and accounted for 20\% of GDP in 2008 [24]. Because it consists of a wide spread of small island atolls, Kiribati also has an enormous exclusive economic marine zone of 3.5 million square kilometres around its coastline. With international recognition of the 200-mile exclusive economic zone (EEZ) by the 1982 Third United Nations Convention on the Law of the Sea, distant water fleets have to pay for access to fishing grounds (previously considered high seas, with free access). Consequently, as Thomas has argued [32], "successive governments in Kiribati have perceived marine resources development... as a means of attaining greater economic independence”. In this way, Kiribati is incorporated into global regimes of international industrial fishing capital, including fleets from Korea, Taiwan, China, Japan, the Philippines and Indonesia.

The development of Kiribati's marine resources has been recommended in numerous plans and reports [33] [35]. However, these reports also cite a poor macroeconomic environment, fragile land environment, small economy, competition from efficient capital-intensive distant-water fishing fleets, inadequate local infrastructure to exploit the fisheries sector efficiently, and the cost and availability of fuel as almost insurmountable barriers to competitive shore-based tuna development. Instead, Kiribati is reliant on rent derived from fishing access fees. In 2010, Kiribati licensed a total of 527 foreign fishing vessels, including supporting vessels such as reefer carriers and tankers. The fees from these foreign fishing vessels contributed to $44 \%$ of the total government revenue and are largely responsible for subsidising the government budget that year [36]. However, these fees account for less than $5 \%$ of the total gross fishing revenue taken from Kiribati's exclusive economic zone (EEZ). Adding a consideration of the role of i-Kiribati labour to this picture, we see that the global fishing industry in producing uneven development has little to do with the wellbeing of i-Kiribati, but everything to do with the enhancement of dominant forms of global power. 


\section{Labour Migration}

Fishing capital circulates in a globalised world, and labour-in the form of migrant workers-also flows across international boundaries. This circulation of labour is one of the most striking aspects of the intense globalisation of the world economy and has a major impact on the labour forces of supply countries. Furthermore, there is a nexus between migration and development that compounds their impact on the social and economic features of nations (including HIV). The development factors influencing migration for work are also likely to shape the development outcomes in resource-poor countries and communities that supply migrant workers [37]. Borovnik argues that this process "leads to a structural division between labour supplying countries (particularly those countries lacking alternative resources for development) and companies in industrial countries taking advantage of the cheap international supply of workers" [38]. This internationalisation of labour and capitalist production has made repeated temporary migration more common [39]-[41].

Transnational seafaring is one of the most potent examples of the integration of Kiribati's economy into what Arrighi calls "global circuits of capital" [42]. As well as the extraction of value from Kiribati's marine resources, as signalled above, the migrant labour of i-Kiribati seafarers is an essential element of Kiribati's MIRAB-type economy. While around 1200 i-Kiribati men are employed as seafarers on (mostly German) merchant ships, there are around 300 - 400, others employed as fishermen on foreign fishing vessels. Until 2006, employment was mostly on Japanese fishing vessels, but since the beginning of 2007, increasing numbers have been employed on Taiwanese and Korean boats. Most seafarers on fishing vessels are trained at the Kiribati Fisheries Training Centre and employed through the agency of Kiribati Fishermen Services, while others on Korean or American fishing vessels are employed through the Ministry of Labour. Onboard ship, Kiribati seafarers are, in effect, permanently mobile. While seafarers inevitably return to their place of origin, they frequently sign on again for periods of work that may extend to an entire working life [43].

Both the global economic crisis and international exploitation of marine resources have had an effect on labour migration of i-Kiribati. The decline in world trade and the lay-up of a number of merchant shipping vessels, together with fish stock depletion, have recently had a flow-on effect on fishing jobs. As ships have been withdrawn from service, the number of employed i-Kiribati seafarers has declined.

Despite being at sea for extended periods, i-Kiribati migrant seafarers retain obligations to family and their remittances are a central part of Kiribati's economy. The economy has been adversely affected as a decline in remittances consequent on reductions in seafarer employment, [23] has been compounded by the depreciation of the United States dollar against the Australian dollar, the national currency of Kiribati [23]. However, remittances continue to play an important role in Kiribati communities, as the populace of this remote nation has few income options. Studies of remittances by seafarers from Kiribati suggest that most funds are spent on meeting basic needs and school fees, with the balance saved to buy land or build a house [38]. Borovnik [38] argues that seafarer remittances of $\$ 10,000$ per man per year are essential, obligatory and institutionalised. As a seafarer's wage is the basis of economic support for between 1 and 30 people, remittances have led to better living conditions for families, increased cash flow and some investment. Loss of employment by individual seafarers due to illness or injury or economic downturn will have serious effects on the economic circumstances of their families. When the level of seafarer unemployment increases, the economic impact will reduce the financial resources of the wider society.

While seafaring does offer the community access to international resources and, in Pacific terms, i-Kiribati seafarers earn relatively high wages of up to US\$1000 per month, the export of relatively cheap i-Kiribati labour to the international fishing and merchant shipping companies perpetuates the unequal nature of the MIRAB economy, which traps small island societies in dependent relations. Seafaring has also profoundly affected sociocultural and demographic structures and subsystems in these economies [44]. And, perhaps more importantly, while the remitted income of seafarers is a positive for families, there is a large social and human cost. Seafaring is a hard life, with most of the men's lives spent away from home-for up to 30 years. This absence from home and the seafaring lifestyle engender considerable pressures on relationships. As Dennis [45] has argued, "among the major impacts are family break-up caused by the infidelity of spouses and, in extreme cases, the abandonment of women and children by men who marry bigamously abroad in order to obtain foreign citizenship" [46] [47]. There are also frequent disagreements about remittance allocation and use [45], and reliance on seafarer remittances also perpetuates gendered power disparities within domestic and family life.

The surrender of the value of natural resources to the industry of other nations, along with a reliance on in- 
come from migrant seafarer labour, underwrites Kiribati's dependence on the share of that value that is returned through remittances and aid programs. In addition, this positioning within global circuits of capital secures Kiribati in an unequal relationship of dependence on industries, interests and forces beyond its shores and outside its influence. These relentless global forces of capital do not enable, but rather limit and disempower, i-Kiribati workers, their families and the community. I-Kiribati have become significantly poorer in the last five years. The International Monetary Fund has indicated that the proportion of i-Kiribati below the poverty line has risen from $21.6 \%$ in 2006 to $26.3 \%$ in 2009, and in South Tarawa, the main town, this proportion had risen from $24.2 \%$ to $30.5 \%$ in the same period.

\section{Kiribati Seafarers and HIV Risk}

[HIV was perceived as] all myths, nobody believed it, nobody... We thought we wouldn't get it, were so far away, so isolated, but then we watched the figures increasing tremendously. (Norati Antera, president of the Kiribati Islands Overseas Seamen's Union [48]).

One of the consequences of seafaring has been its effect on HIV risk and prevalence in Kiribati. Internationally, there is considerable evidence that seafarers, as a mobile population in an industry of critical economic importance to local populations, are at particular risk of acquiring HIV. Oriente describes Pacific Island seafarers as "an itinerant, typically all-male work force who spends long periods at sea away from home. While at sea, cultural factors that contribute to risk taking among this group generally fall under the heading of the 'seafaring lifestyle’” [48].

These long periods away from home, shipboard and port mateship cultures, and infrequent condom use in casual and paid sexual relations while in overseas ports, exacerbated by heavy alcohol use, have rendered i-Kiribati seafarers—along with their wives and girlfriends — the group most vulnerable to HIV in Kiribati [49].

Currently, $63 \%$ of the reported HIV cases in Kiribati are male-more than half of these are seafarers, and most cases were reported in South Tarawa, the capital. Some of these men have also infected their wives. While numbers of HIV infections in Kiribati are low, there are indications of some of the proximate drivers of HIV among seafarers: high STI rates, paying for sex while at sea, and low condom use [50].

Three second-generation surveillance surveys have been held among i-Kiribati seafarers since 2003 [51] [52]. The results suggest that, while knowledge of HIV prevention and transmission improved from 2005 to 2008, this did not correlate with reduced levels of risky sexual activity in the same period [52]. While most seafarers are aware that condoms can prevent HIV transmission, very few use them. The results for 2005 and 2008 indicate that the percentage of seafarers with "casual partners in the last 12 months" rose dramatically, as did the percentage of seafarers who had "paid for sex in the last 12 months" [52]. On the other hand, condom use dropped noticeably between 2005 and 2008. Armstrong [53], Peteru [54] and the World Health Organization [51] all reported the same finding: the majority of seafarers do not use condoms at sea or at home. In one survey, $79 \%$ of i-Kiribati sailors [45] admitted that they were often too drunk to think about risk and, even if they had condoms with them, were too drunk to remember to use them. Many seafarers also stated that they have never been shown how to use a condom [53]-[55].

Kiribati seafarers typically subscribe to the traditional gender roles and attitudes that remain dominant in the region, and are resistant to talking openly about sex and sexual health or negotiating safe sex with their partners. While the findings discussed above, which show a decrease in condom use along with an increase in risk behaviours, give rise to questions about HIV prevention education efforts among seafarers, it is clear that the HIV vulnerability of this group of i-Kiribati men (and that of their wives and girlfriends) is not purely an outcome of their sexual behaviour. Their susceptibility to infection is a reflection of Kiribati's political economy—one that is highly dependent on the remittances that these men provide and where choice about profession and the conditions of that work are highly proscribed.

\section{I-Kiribati Women}

Labour force participation in Kiribati is the lowest of any Pacific country [56] and opportunities for young people are extremely limited; the young make up $58 \%$ of the unemployed. If the choices available to i-Kiribati young men are circumscribed, those of young women are even more so.

Women's experience of dependent development in Kiribati is shaped by the interaction of a wide range of factors. Traditionally, i-Kiribati society was patrilineal, with women subordinate to their fathers, husbands and 
te unimane (male elders or old men) [57]. I-Kiribati society and culture are still conservative and male dominated. While the status of women is changing, the subservient role of women is generally accepted by both men and women. Gender roles remain quite strictly defined. Women help with farming and fishing, but also have primary responsibility for family caretaking, cooking and all household duties. Women are expected to be obedient and faithful, to defer to their husband on decision-making, and to bear children, while "physical punishment is often used as a form of disciplining women who are seen as stepping outside of their prescribed gender roles” [58].

Indeed, violence against women is commonplace in Kiribati. In a study carried out by the Secretariat of the Pacific Community in Kiribati in 2010, 68\% of women (ages 15 - 49) ever in a relationship reported experiencing physical and/or sexual violence by an intimate partner [58]. This prevalence is among the highest in the world. The public health consequences of violence against women are also significant [59], as violence places women at higher risk for poor physical and reproductive health, mental health and social functioning [51]. In Kiribati, sexual and physical violence is largely unreported because of social and cultural pressures from family members, and customs of forgiveness. As well, customary laws of land ownership, which have become codified into statutory laws in Kiribati, stipulate that in the distribution of an estate between sons and daughters, the share of the eldest son should exceed the shares of his brothers, and the shares of sons should exceed the shares of daughters. It is in this context of high unemployment, overcrowded living conditions, a culture of hardship and the domestic oppression of young women, and the endemic nature of physical and sexual abuse that some young women in the two major port towns choose to work on board foreign fishing vessels selling sex.

\section{Ainen Matawa: Kiribati Women Who Sell Sex on Foreign Fishing Vessels}

In Kiribati, the term ainen matawa refers to women and girls who board foreign fishing vessels and engage in sex with seafarers in exchange for money and goods. Young i-Kiribati women have few opportunities for secure well-paid work and little control of local resources or access to commodities and consumer goods, making sex work a viable choice for some. There is no doubt that the global sex industry is structured by exploitation and poverty, and that sex work in many countries is a product of global economic inequality [60]. However, it would be wrong to view ainen matawa as purely victims and having no agency. The actuality is a complex mix of exclusion and marginalisation, and desire for a better life on the part of the young women themselves. Toatu [61] identified the major factors associated with sex work on board foreign fishing vessels as being limited education, lack of employment opportunities, and access to alcohol.

The numbers of ainen matawa are increasing in major ports of Kiribati. In 2003, the number of women involved on South Tarawa was estimated to be between 30 and 50. It is currently estimated at around 80 [62]. There is concern that ainen matawa are at risk of HIV from their foreign paying partners, but at the same time these young women are identified as posing a risk to wider society by being a potential conduit for HIV. A 2006 survey of ainen matawa [61] found no HIV; however, 58\% of the participants had one or more STI. The same study found that the women had a good awareness of HIV and condoms, but that condom use was intermittent only. McMillan and Worth carried out a qualitative study of ainen matawa in 2010, which aimed to investigate the circumstances and context of local sex work in Tarawa-especially ship sex work-and to understand factors impacting on vulnerability to HIV transmission and condom use behaviours. The study also examined the wider context of the young women's relationships with their own i-Kiribati community and with foreign seafar$\mathrm{ers}^{2}$. Data collected in that study indicate that while the sexual relationships with clients are clearly predicated on the exchange of sex and goods, the women generally stay with one client while on board a boat- for up to three months - in a pattern of paid sex relationships that could be characterised as serial monogamy. The women are generally not paid for each sexual encounter, but receive payment when they leave the boat. While these relationships are viewed by the women as economic transactions, many ainen matawa refer to these men, with whom they have a clearly defined economic relationship, as "little husbands". This is a very different pattern from that usually associated with sex work, but it makes clear the connections and tensions between domestic sex and sex work, and between the stereotype of sex work as lacking emotion-what Hua and Ray [63] call the "almost mechanical, inhumane provision of set sexual services"-and the so-called intimacy and care inherent

${ }^{2}$ The study [62] comprised 25 in-depth interviews with ainen matawa. It was funded by Aus AID, conducted in partnership with the Pacific STI and HIV Research Centre (PSHRC) of the Fiji National University, and supported by KANGO (a local NGO) and peer interviewers. Ethical approval was obtained from the Kiribati Ministry of Health and the UNSW Human Research Ethics Committee. 
in domestic sex. The work of these ainen matawa captures more recent global forms of labour arrangements and redraws the boundaries between public and private life, and between intimacy and commerce. For these women, sex work is invested by the emotional and affective labour once associated with the intimate or domestic. Emotional labour and intimacy are transported from the sphere of domesticity to that of commerce [64].

If this is a pattern of sexual exchange that has similarities to that of long-term heterosexual relationships, it is also a pattern that makes consistent condom use problematic. Most participants said that consistent condom use occurs for only the first week or two of the relationship, and then ceases. Having multiple sequential seafarer partners may in fact generate greater vulnerabilities and risks compared to regular i-Kiribati wives and girlfriends of seafarers.

It must be noted that these relationships with foreign seafarers are frequently characterised by emotional intimacy and trust. Indeed, the women considered their relationships on board ship as being safe and secure in comparison to life onshore. Local men were seen as being less caring, more aggressive and controlling, and more sexually exploitative than the seafarers. The participants said that they seldom have regular local boyfriends or husbands at the same time as they are boarding boats. However, their very identity as ainen matawa renders them vulnerable to rape and sexual abuse from local men, including the police. In addition, they experience considerable marginalisation. Many have been beaten and disowned by their families because of their sex work.

\section{Conclusions}

This article has brought a consideration of the political economy of Kiribati together with empirical data on the sexual behaviour and lives of both i-Kiribati seafarers and ainen matawa and the specific context of social life in this small Pacific island state. While the choices and options that underwrite HIV risk for individuals in both of these social groups play out on a small and very personal stage, the shapes of their most intimate relationships are determined also by the social and cultural specificities of Kiribati, and are forged in the realm of global politics of the extraction of value. The lives of both i-Kiribati seafarers and ainen matawa are caught up in global processes that are outside their control—local seafarers by virtue of their assimilation into a global shipping industry as transnational labour, and ainen matawa through their economic reliance on providing sexual and other intimate services to the crew of international fishing fleets.

Positioned at the periphery of, but enmeshed in, the global economy, Kiribati as a nation faces a lack of choice as to its future. An effective local fishing industry is impossibility, and the only solution put forward seems to be privatisation of the public sector [56]. There is growing evidence of poverty as a daily reality for a significant proportion of the population [24] [65]. Job creation prospects are limited in Kiribati, and migration is an option for only a few. This lack of autonomy at a national level is reprised in i-Kiribati social relations as the constraint and shaping of individual choice in terms of labour (seafaring or sex work) and, indeed, intimates relationships. The global forces that underwrite Kiribati's dependency penetrate into the arena of intimacy, sexual relationships and the personal choices of the populace- territory where HIV risk plays out. In Kiribati, HIV risk and vulnerability are generated by conditions external to i-Kiribati themselves, far beyond the sphere of local control and of individual behaviour. I-Kiribati labour, whether it is sex work or seafaring, is part of what Comaroff calls the "intensified circulation of persons and things in the world" [66]. At the same time, though, "no world-transforming force exists without the engagement of tangible human agents and interests... all activities, large and small, which can be shown to have social and cultural determinations and, hence, are susceptible to debate, contestation, and intervention" [66]. It is just such an engagement that will be required if the constraints of dependence are to be loosened. For i-Kiribati, both seafarers and sex workers, this contestation will be the space of engagement in their own futures.

\section{References}

[1] Comaroff, J. (2007) Beyond Bare Life: AIDS, (Bio)Politics, and the Neoliberal Order. Public Culture, 19, $197-219$. http://dx.doi.org/10.1215/08992363-2006-030

[2] Potts, M., Halperin, D., Swidler, A., Marseille, E., Klausner, J., Hearst, N., Wamai, R., Kahn, J. and Walsh, J. (2008) Reassessing HIV Prevention. Science, 320, 749-750.

[3] Maggiolo, F. and Leone, S. (2010) Is HAART Modifying the HIV Epidemic? The Lancet, 376, 492-493. http://dx.doi.org/10.1016/S0140-6736(10)61057-4 
[4] Rhodes, T., Singer, M., Bourgois, P., Friedman, S. and Strathdee, S. (2005) The Social Structural Production of HIV Risk among Injecting Drug Users. Social Science \& Medicine, 61, 1026-1044. http://dx.doi.org/10.1016/j.socscimed.2004.12.024

[5] Parker, R., Easton, D. and Klein, C. (2000) Structural Barriers and Facilitators in HIV Prevention: A Review of International Research. AIDS, 14, S22-S32. http://dx.doi.org/10.1097/00002030-200006001-00004

[6] Singer, M. (1998) Forging a Political Economy of AIDS. In: Singer, M., Ed., The Political Economy of AIDS, Baywood Publishing Company, New York.

[7] Auerbach, J., Parkhurst, J. and Caceres, C. (2011) Addressing Social Drivers of HIV/AIDS for the Long-Term Response: Conceptual and Methodological Considerations. Global Public Health: An International Journal for Research, Policy and Practice, 6, S293-S309. http://dx.doi.org/10.1080/17441692.2011.594451

[8] Fourie, P. (2006) The Political Management of HIV and AIDS in South Africa: One Burden Too Many? Palgrave Macmillan, Basingstoke. http://dx.doi.org/10.1057/9780230627222

[9] Foller, M. and Thorn, H. (2008) The Politics of AIDS: Globalization, the State and Civil Society. Palgrave Macmillan, New York.

[10] Collins, J. and Rau, B. (2000) AIDS in the Context of Development. United Nations Research Institute for Social Development, Geneva.

[11] Altman, D. (1999) Globalization, Political Economy, and HIV/AIDS. Theory and Society, 28, 559-584. http://dx.doi.org/10.1023/A:1007061910035

[12] Poku, N. (2002) Poverty, Debt and Africa’s HTV/AIDS Crisis. International Affairs, 78, 531-546. http://dx.doi.org/10.1111/1468-2346.00265

[13] Biccum, R. (2005) Development and the "New” Imperialism: A Reinvention of Colonial Discourse in DFID Promotional Literature. Third World Quarterly, 26, 1005-1020. http://dx.doi.org/10.1080/01436590500139656

[14] World Bank (2013) Data: Kiribati. http://data.worldbank.org/country/kiribati

[15] Country Coordinating Mechanism, Kiribati (2012) Global AIDS Response, Kiribati Country Progress Report 2012. Government of Kiribati, Tarawa.

[16] Onorio, T. (2011) Statement of the Republic of Kiribati, Delivered by the Vice President Honourable Teima Onorio. Presented at the High-Level Meeting of the 65th Session of the United Nations General Assembly on HIV and AIDS, New York, 9 June 2011.

[17] Comaroff, J. and Comaroff, J. (2003) Ethnography on an Awkward Scale: Postcolonial Anthropology and the Violence of Abstraction. Ethnography, 4, 147-179. http://dx.doi.org/10.1177/14661381030042001

[18] Morgan, L. (1987) Dependency Theory in the Political Economy of Health: An Anthropological Critique. Medical Anthropology Quarterly, 1,131-154. http://dx.doi.org/10.1525/maq.1987.1.2.02a00010

[19] Appadurai, A. (1996) Modernity at Large: The Cultural Dimensions of Globalization. University of Minnesota Press, Minneapolis.

[20] Appadurai, A. (1997) Discussion: Fieldwork in the Era of Globalization. In: Bamford, S. and Robbins, J., Eds., Anthropology and Humanism, 22,115-118.

[21] Farmer, P. (1996) AIDS and Accusation: Haiti and the Geography of Blame. University of California Press, ,Berkeley.

[22] Bertram, G. (1999) The MIRAB Model Twelve Years On. The Contemporary Pacific, 11, 105-138.

[23] United Nations Development Programme (2010) Human Development Report 2010-20th Anniversary Edition. The Real Wealth of Nations: Pathways to Human Development. United Nations Development Programme, New York.

[24] AusAID (2009) Pacific Economic Survey 2008: Connecting the Region. Australian Agency for International Development (AusAID), Canberra.

[25] Hache, J.D. (1998) Towards a Political Approach to the Island Question. In: Baldacchino, G. and Greenwood, R., Eds., Competing Strategies of Socio-Economic Development for Small Islands, Institute of Island Studies, Charlottetown.

[26] International Monetary Fund (2009) Kiribati: Selected Issues and Statistical Appendix. IMF Country Report No. 09/ 196.

[27] Bertram, I.G. and Watters, R.F. (1985) The MIRAB Economy in South Pacific Microstates. Pacific Viewpoint, 26, 497-519.

[28] International Labour Organization (2010) Decent Work Country Programme: Kiribati.

[29] International Monetary Fund (2011) Kiribati: 2011 Article IV Consultation-Staff Report, Informational Annexes, Debt Sustainability Analysis, Public Information Notice on the Executive Board Discussion, and Statement by the Executive Director for Kiribati. IMF Country Report No. 11/113. 
[30] Denoon, D. (1997) Emerging from Empire? Decolonisation in the Pacific. Division of Pacific and Asian History, Australian National University, Canberra.

[31] Connell, J. (2006) Migration, Dependency and Inequality in the Pacific: Old Wine in Bigger Bottles? (Part 1). Policy, 20, 74-102.

[32] Thomas, F. (2003) Fisheries Development in Kiribati: Sustainability Issues in a "MIRAB” Economy. Pacific Studies, 26, 1-35.

[33] Ministry of Finance and Economic Development (2010) National Assessment Report of the Maritime Strategy for Further Implementation of the Barbados Program of Action for Sustainable Development in Small Island Developing States. Government of Kiribati, Tarawa.

[34] International Monetary Fund (2013) Article IV Consultation. Concluding Statements on the IMF Mission. http://www.imf.org/external/np/ms/2013/040913.htm

[35] Government of Kiribati (2012) Kiribati Development Plan 2012-2015: Enhancing Growth for Sustainable Development-A Vibrant Economy for the People of Kiribati. Government of Kiribati, Tarawa.

[36] Western and Central Pacific Fisheries Commission (2011) Annual Report to the Commission. Part 1: Information on Fisheries, Research, and Statistics. Scientific Committee Seventh Regular Session. Pohnpei, Federated States of Micronesia, WCPFC-SC7-AR/CCM-10.

[37] Taylor, J. (1999) The New Economics of Labor Migration and the Role of Remittances. International Migration, 37, 63-86. http://dx.doi.org/10.1111/1468-2435.00066

[38] Borovnik, M. (2006) Working Overseas: Seafarers' Remittances and Their Distribution in Kiribati. Asia Pacific Viewpoint, 47, 151-161. http://dx.doi.org/10.1111/j.1467-8373.2006.00298.x

[39] Portes, A., Guarnizo, L. and Landolt, P. (1999) The Study of Transnationalism: Pitfalls and Promise of an Emergent Research Field. Ethnic and Racial Studies, 22, 217-237. http://dx.doi.org/10.1080/014198799329468

[40] Tsuda, T. (1999) The Permanence of “Temporary” Migration: The "Structural Embeddedness” of Japanese-Brazilian Immigrant Workers in Japan. Journal of Asian Studies, 58, 687-722. http://dx.doi.org/10.2307/2659116

[41] Duany, J. (2002) Mobile Livelihoods: The Sociocultural Practices of Circular Migrants between Puerto Rico and the United States. International Migration Review, 36, 355-388. http://dx.doi.org/10.1111/j.1747-7379.2002.tb00085.x

[42] Arrighi, G. (2002) The African Crisis: World Systemic and Regional Aspects. New Left Review, 15, 5-36.

[43] Borovnik, M. (2004) Are Seafarers Migrants? Situating Seafarers in the Framework of Mobility and Transnationalism. New Zealand Geographer, 60, 36-43. http://dx.doi.org/10.1111/j.1745-7939.2004.tb01703.x

[44] Hayes, G. (1991) Migration, Metascience and Development Policy in Island Polynesia. The Contemporary Pacific, 3, 1-58.

[45] Dennis, J. (2003) Pacific Island Seafarers: A Study of the Economic and Social Implications of Seafaring on Dependants and Communities. Secretariat of the Pacific Community, Suva.

[46] Maclellan, N. and Mares, P. (2005) Labour Mobility in the Pacific: Creating Seasonal Work Programs in Australia. Proceedings of Globalisation, Governance and the Pacific Islands Conference, State, Society and Governance in Melanesia Project, Canberra, 25-27 October, 137-171.

[47] Maclellan, N. (2008) Workers for All Seasons? Issues from New Zealand's RSE Program. Institute for Social Research, Swinburne University of Technology, Melbourne.

[48] Oriente, R. (2006) HIV/AIDS and Pacific Island Regional Fishers and Seafarers: Information, Education and Communications Needs and Available Resources. In: Anderson, K.L. and Thierry, C., Eds., Information for Responsible Fisheries: Libraries as Mediators, Proceedings of the 31st Annual Conference, Rome, 10-14 October 2005, Fort Pierce, International Association of Aquatic and Marine Science Libraries and Information Centers, 155-170.

[49] Connell, J. and Negin, J. (2010) Migration, Mobility and HIV: A Rapid Assessment of Risks and Vulnerabilities in the Pacific. United Nations Development Programme and Secretariat of the Pacific Community, Suva.

[50] Vunisea, A. (2005) HIV Risks through the Tuna Industry. Women in Fisheries, 15, 7-9.

[51] World Health Organization, Regional Office of the Western Pacific (2005) STI/HIV Prevalence Surveys of Sexually Transmitted Infections among Seafarers and Women Attending Antenatal Clinics in Kiribati 2002-2003. World Health Organization, Manila.

[52] Government of Kiribati and Secretariat for the Pacific Community (2008) Second Generation Surveillance of Antenatal Women, Seafarers, Policemen and Youth, Kiribati. Secretariat of the Pacific Community, Noumea.

[53] Armstrong, W. (1998) HIV/AIDS and STD among Seafarers in the Pacific Region: A Situation Analysis. Secretariat of the Pacific Community, Noumea.

[54] Peteru, P. (2002) Pacific Island Seafarers: A Study on HIV/AIDS and STI Risk-Related Behavior. Secretariat of the 
Pacific Community, Noumea.

[55] Borovnik, M. (2003) Seafarers in Kiribati: Consequences of International Labour Circulation. Ph.D. Dissertation, University of Canterbury, Christchurch.

[56] Asian Development Bank (2007) Key Indicators of Developing Asian and Pacific Countries 2007. Asian Development Bank, Manila.

[57] Chung, M. (2005) Kiribati Islands: A Situation Analysis of Children, Women and Youth. UNICEF Pacific Office, Fiji.

[58] Secretariat of the Pacific Community (2010) Kiribati Family Health and Safety Study: A Study on Violence against Women and Children. Secretariat of the Pacific Community, Noumea.

[59] Ellsberg, M., Jansen, H.A., Heise, L., Watts, C.H. and Garcia-Moreno, C. (WHO Multi-Country Study on Women's Health and Domestic Violence against Women Study Team) (2008) Intimate Partner Violence and Women’s Physical and Mental Health in the WHO Multi-Country Study on Women's Health and Domestic Violence: An Observational Study. The Lancet, 371, 1165-1172. http://dx.doi.org/10.1016/S0140-6736(08)60522-X

[60] Padilla, M. (2007) The Embodiment of Tourism among Bisexually-Behaving Dominican Male Sex Workers. Archives of Sexual Behavior, 37, 783-793. http://dx.doi.org/10.1007/s10508-008-9358-5

[61] Toatu, T. (2007) Prevalence of Behavioural Risk Factors and Selected STIs and HIV among Young Women Boarding Foreign Fishing Vessels in Kiribati. M.Sc. Dissertation, University of Sydney, Sydney.

[62] McMillan, K.E. and Worth, H. (2010) Risky Business in Kiribati: HIV Prevention and Women Who Board Foreign Fishing Vessels in Tarawa. International HIV Research Group, University of New South Wales, Sydney. http://www.sphcm.med.unsw.edu.au/SPHCMWeb.nsf/resources/Kiribati_Report.pdf/\$file/Kiribati_Report.pdf

[63] Hua, J. and Ray, K. (2010) The "Practice of Humanity”. Feminist Media Studies, 10, 253-267. http://dx.doi.org/10.1080/14680777.2010.493644

[64] Bernstein, E. (2007) Temporarily Yours: Intimacy, Authenticity, and the Commerce of Sex. University of Chicago Press, Chicago. http://dx.doi.org/10.7208/chicago/9780226044620.001.0001

[65] Thomas, F. and Tonganibeia, K. (2007) Pacific Island Rural Development: Challenges and Prospects in Kiribati. In: Connell, J. and Waddell, E., Eds., Environment, Development and Change in Rural Asia-Pacific: Between Local and Global, Routledge Pacific Rim Geographies, Routledge, Oxon, 38-55.

[66] Comaroff, J. (n.d.) Ethnography-The Paradox, Intrinsic Features, the Native’s Point of View? Ethnography and Globalization. http://science.jrank.org/pages/7676/Ethnography.html 
Scientific Research Publishing (SCIRP) is one of the largest Open Access journal publishers. It is currently publishing more than 200 open access, online, peer-reviewed journals covering a wide range of academic disciplines. SCIRP serves the worldwide academic communities and contributes to the progress and application of science with its publication.

Other selected journals from SCIRP are listed as below. Submit your manuscript to us via either submit@scirp.org or Online Submission Portal.
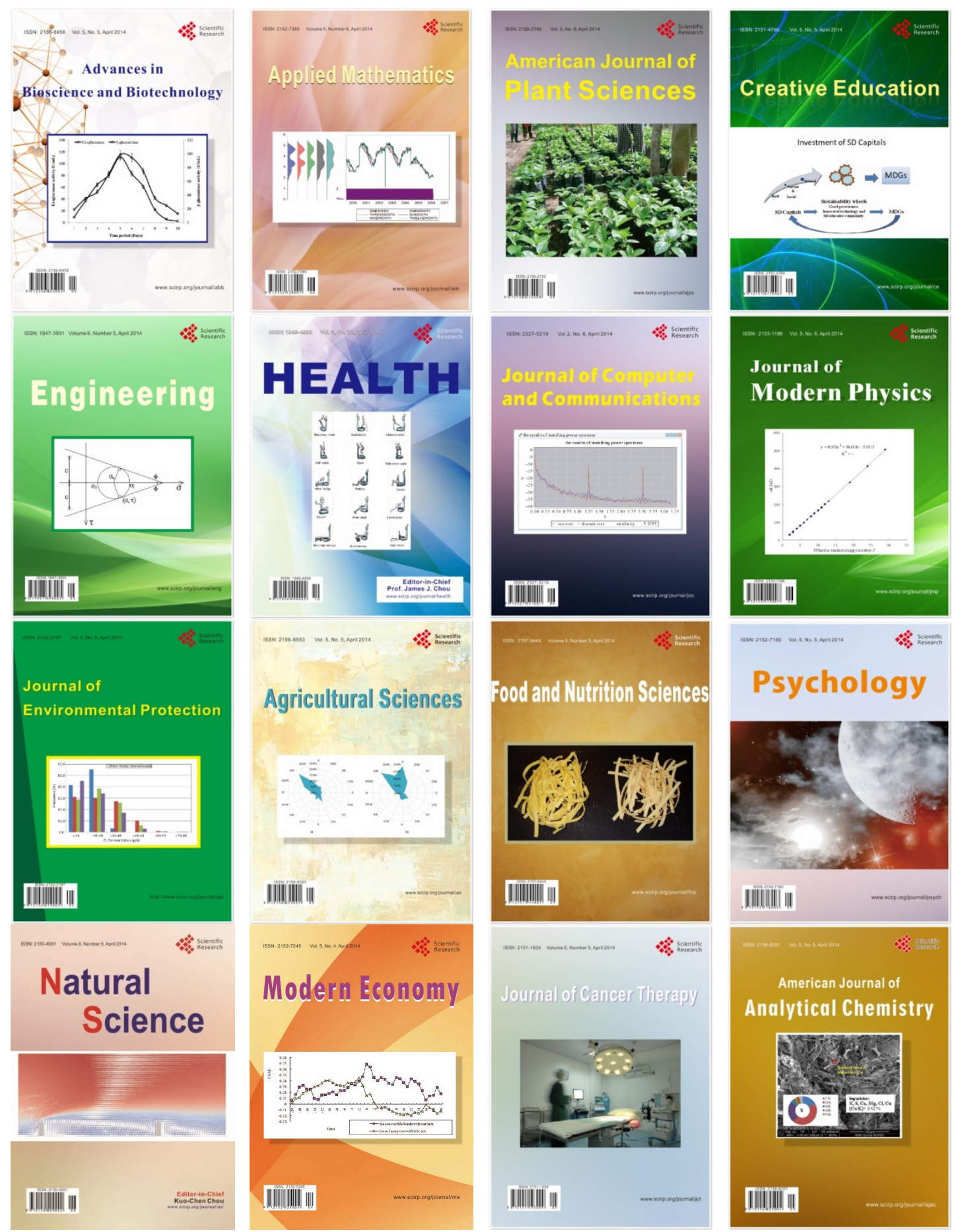